\title{
Methane dynamics in three different Siberian water bodies under winter and summer conditions
}

\author{
Ingeborg Bussmann ${ }^{1}$, Irina Fedorova ${ }^{2}$, Bennet Juhls ${ }^{3}$, Pier Paul Overduin ${ }^{4}$, and Matthias Winkel ${ }^{5, a}$ \\ ${ }^{1}$ Alfred Wegener Institute Helmholtz Centre for Polar and Marine Research, Helgoland, Germany \\ ${ }^{2}$ Institute of Earth Sciences, St. Petersburg University, St. Petersburg, Russia \\ ${ }^{3}$ Institute for Space Sciences, Department of Earth Sciences, Freie Universität Berlin, Berlin, Germany \\ ${ }^{4}$ Alfred Wegener Institute Helmholtz Centre for Polar and Marine Research, Potsdam, Germany \\ ${ }^{5}$ German Research Centre for Geoscience, 3.7 Geomicrobiology Group, Potsdam, Germany \\ acurrent address: German Research Centre for Geosciences, 3.5 Interface Geochemistry Group, Potsdam, Germany
}

Correspondence: Ingeborg Bussmann (ingeborg.bussmann@awi.de)

Received: 24 March 2020 - Discussion started: 22 April 2020

Revised: 31 December 2020 - Accepted: 13 February 2021 - Published: 22 March 2021

\begin{abstract}
Arctic regions and their water bodies are affected by a rapidly warming climate. Arctic lakes and small ponds are known to act as an important source of atmospheric methane.
\end{abstract}

However, not much is known about other types of water bodies in permafrost regions, which include major rivers and coastal bays as a transition type between freshwater and marine environments. We monitored dissolved methane concentrations in three different water bodies (Lena River, Tiksi Bay, and Lake Golzovoye, Siberia, Russia) over a period of 2 years. Sampling was carried out under ice cover (April) and in open water (July-August). The methane oxidation (MOX) rate and the fractional turnover rate $\left(k^{\prime}\right)$ in water and melted ice samples from the late winter of 2017 was determined with the radiotracer method.

In the Lena River winter methane concentrations were a quarter of the summer concentrations $\left(8 \mathrm{nmol} \mathrm{L}^{-1}\right.$ vs. $31 \mathrm{nmol} \mathrm{L}^{-1}$ ), and mean winter MOX rate was low $\left(0.023 \mathrm{nmol} \mathrm{L}^{-1} \mathrm{~d}^{-1}\right)$. In contrast, Tiksi Bay winter methane concentrations were 10 times higher than in summer $\left(103 \mathrm{nmol} \mathrm{L}^{-1}\right.$ vs. $\left.13 \mathrm{nmol} \mathrm{L}^{-1}\right)$. Winter MOX rates showed a median of $0.305 \mathrm{nmol} \mathrm{L}^{-1} \mathrm{~d}^{-1}$. In Lake Golzovoye, median methane concentrations in winter were 40 times higher than in summer $\left(1957 \mathrm{nmol} \mathrm{L}^{-1}\right.$ vs. $\left.49 \mathrm{nmol} \mathrm{L}^{-1}\right)$. However, MOX was much higher in the lake $\left(2.95 \mathrm{nmol} \mathrm{L}^{-1} \mathrm{~d}^{-1}\right)$ than in either the river or bay. The temperature had a strong influence on the $\operatorname{MOX}\left(Q_{10}=2.72 \pm 0.69\right)$. In summer water temperatures ranged from $7-14^{\circ} \mathrm{C}$ and in winter from -0.7 to $1.3^{\circ} \mathrm{C}$. In the ice cores a median methane concentration of $9 \mathrm{nM}$ was observed, with no gradient between the ice surface and the bottom layer at the ice-water interface. MOX in the (melted) ice cores was mostly below the detection limit. Comparing methane concentrations in the ice with the underlaying water column revealed methane concentration in the water column 100-1000 times higher.

The winter situation seemed to favor a methane accumulation under ice, especially in the lake with a stagnant water body. While on the other hand, in the Lena River with its flowing water, no methane accumulation under ice was observed. In a changing, warming Arctic, a shorter ice cover period is predicted. With respect to our study this would imply a shortened time for methane to accumulate below the ice and a shorter time for the less efficient winter MOX. Especially for lakes, an extended time of ice-free conditions could reduce the methane flux from the Arctic water bodies.

\section{Introduction}

Worldwide, the mixing ratio of methane has been increasing rapidly since 2000 , from $2.1 \mathrm{ppbyr}^{-1}$ for the time span 2000-2009 to $6.6 \mathrm{ppb} \mathrm{yr}^{-1}$ for the time span 20082017 and to $6.1 \mathrm{ppbyr}^{-1}$ in 2017 (Saunois et al., 2020). Understanding and quantifying the global methane budget is important for assessing realistic pathways to mitigate climate change. For the 2008-2017 decade, global 
methane emissions are estimated by a top-down approach to be $576 \mathrm{Tg} \mathrm{CH}_{4} \mathrm{yr}^{-1}$ (range 550-594, corresponding to the minimum and maximum estimates of the model ensemble) (Saunois et al., 2020). The reasons for the observed increases in atmospheric methane are unclear. A probable explanation is increased methane emissions from wetlands, both in the tropics (Nisbet et al., 2016) and in the Arctic (Fisher et al., 2011), and from other Arctic water bodies (Walter Anthony et al., 2016; Kohnert et al., 2018) or geological methane emissions (Kohnert et al., 2017). Especially in northern latitudes, natural wetlands contribute $59 \%$ to the northern methane emissions (Saunois et al., 2020). In the Arctic, the mean atmospheric methane mixing ratio increased by $6 \mathrm{ppbyr}^{-1}$ from 2001 to 2017 , resulting in an atmospheric mole fraction of $1939 \mathrm{ppb}$ in 2017 at Svalbard (Platt et al., 2018) and with a median of 1932 ppb in 2017 for Tiksi (Hydrometeorological Observatory of Tiksi, Russia). In particular the Laptev Sea, in eastern Siberia, is generally a source of methane to the atmosphere, and the sea-air flux of methane is mainly affected by increasing water temperatures (Wåhlström et al., 2016). Also, Saunois and co-authors estimated increased methane emission for freshwater systems and wetlands, but a better quantification of the emissions of different contributors (streams, rivers, lakes, and ponds) is needed (Saunois et al., 2016).

Lakes are important sources of atmospheric methane on a regional to global scale (Bastviken et al., 2004; Cole et al., 2007), and their contribution is predicted to increase in response to climate change and rapidly warming waters (O'Reilly et al., 2015; Tan and Zhuang, 2015; Wik et al., 2018). Most of the methane produced in lake sediments enters the atmosphere via ebullition (Bastviken et al., 2004; Walter et al., 2007), a temperature-sensitive transport mode with high spatial and temporal heterogeneity (DelSontro et al., 2015). The role of Arctic rivers as a methane source to the shelf seas is poorly described. Some studies present rivers as strong methane sources (Morozumi et al., 2019), while other studies revealed a complex pattern of riverine methane input (Bussmann et al., 2017).

One major drawback from most of these studies is that sampling was conducted in the ice-free season, although most of the year Arctic water bodies are ice covered. Thus, the seasonal variation could not be captured within those studies. The ice cover on lakes decouples the water body from the atmosphere and the circulation changes from winddriven to thermohaline. After ice formation a stable winter stratification is set up. As there is no more external oxygen supply, enhanced anaerobic degradation leads to accumulation of methane, $\mathrm{H}_{2} \mathrm{~S}$ and $\mathrm{NH}_{3}$ (Leppäranta, 2015). In several lakes in Alaska and Canada, dissolved methane was highest under the ice cover, indicating that the spring ice-off period is a large source of atmospheric methane (Townsend-Small et al., 2017; Cunada et al., 2018; Serikova et al., 2019). In lakes at $>65^{\circ} \mathrm{N}$ the ice duration is 9 months, typically from around mid-September to mid-June (Cortés and MacIntyre,
2020). However, the hydrography of a lake is also an important factor to consider since stratification of the water column counteracts an intense gas exchange. Thus, examples are known for lakes with incomplete spring mixing and consequently a maximum gas exchange in autumn during complete mixing (Deshpande et al., 2015).

Rivers of permafrost regions are characterized by an ice season of $>100 \mathrm{~d}$ duration between autumn freeze-up, and spring ice-off; for the Lena River it is $>160 \mathrm{~d}$ (Shiklomanov and Lammers, 2014). Ice effects and the demobilization of liquid water result in very low discharge during winter freeze-up and runoff is lowest during late winter (Lininger and Wohl, 2019). A decrease in ice thickness of the largest Siberian rivers during the last 10 to 15 years (Shiklomanov and Lammers, 2014) could enhance the channel connectivity to subchannel and groundwater flow, causing an increase in winter base flow, as suggested by Gurevich (2009). An increased winter flow and increasing temperatures in the Lena River are also supported by Tananaev et al. (2016), Yang et al. (2002), and Peterson et al. (2002).

An important filter, counteracting the methane flux into the atmosphere, is microbial methane oxidation. Methane can be oxidized under anoxic conditions close to sediment horizons where it is produced (Martinez-Cruz et al., 2017; Winkel et al., 2018) or during migration through the oxic water column to the atmosphere (Mau et al., 2017a; Bussmann et al., 2017). Under ice cover, it is important to consider methane oxidation below ice as it may reduce the total amount of methane emitted to the atmosphere during ice-off. Active methane oxidation and a methanotrophic community have been shown for permafrost thaw ponds and lakes (Kallistova et al., 2019). Yet, the methane oxidation capacity in such lakes during ice cover with low temperatures and low oxygen concentrations is unknown. In a study covering several boreal lakes, methane oxidation was restricted to three lakes, where the phosphate concentrations were highest (Denfeld et al., 2016). Rates of methane oxidation during the winter have been found to be much lower than summer rates, yet there is no clear consensus on the factors limiting methane oxidation in winter (Ricão Canelhas et al., 2016). In addition to oxygen concentration, the geological background (i.e., yedoma-type permafrost lakes versus non-yedoma-type lakes) also had a significant impact on the methane oxidation rate (MartinezCruz et al., 2015).

Our study tests the hypothesis that winter ice blocks methane emissions, leading to the accumulation of methane in the underlying water bodies. By studying hydrographically different water bodies (lake, river, and sea), we expect insights into the influence of water column dynamics on methane accumulation to result. In addition, we measure methane oxidation rates in the water column and in melted ice to assess oxidation as a potential sink. 


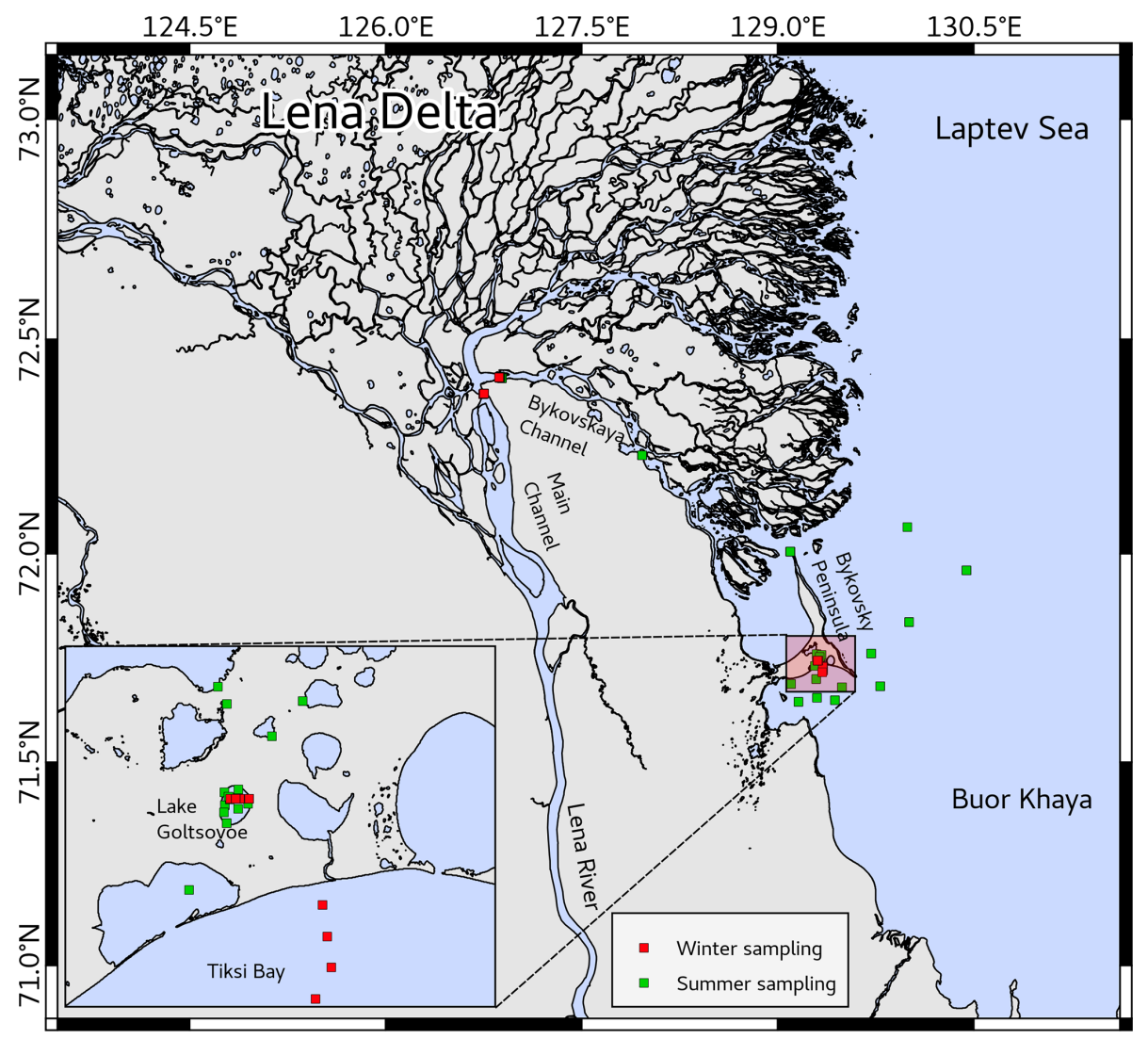

Figure 1. Map of the study area in the Lena River and Buor-Khaya Bay (Siberia, Russia). The inset shows details of the sampling at Lake Golzovoye. Sampling locations in winter are shown in red and summer sampling locations in green. Created by Bennet Juhls.

\section{Study area}

This study was conducted on the southern coast of Bykovsky Peninsula in northeast Siberia, Russia (Fig. 1). Thermokarst lakes in that area commonly originated in the early Holocene when surficial permafrost started to thaw, leading to accumulation of lake sediments with organic contents of about 5\%-30\% (Biskaborn et al., 2016; Schleusner et al., 2015). Thermokarst lakes in the Lena River delta seem to be ice free a little later after the coastal ice breakup, depending strongly on the air temperature in the individual year (Bennet Juhls, unpublished data).

Offshore of the Bykovsky Peninsula, part of the Yedoma Ice Complex is submerged, and subsea permafrost is currently degrading. The coastline erodes at mean rates of between 0.5 and $2 \mathrm{~m} \mathrm{yr}^{-1}$ and can intersect inland water bodies, draining them or leading to the formation of thermokarst lagoons (Lantuit et al., 2011). The sea ice season in Tiksi Bay and the Buor-Khaya Bay typically starts in late Septemberearly October and ends in beginning-mid-July (Angelopoulos et al., 2019; Janout et al., 2020). Due to its isolation behind Muostakh Island and Cape Muostakh, sea ice tends to be preserved longer than in the central Laptev Sea, resulting in approx. $96 \mathrm{~d}$ of open water (Günther et al., 2015).
The Lena River has a mean annual discharge of $581 \mathrm{~km}^{3} \mathrm{yr}^{-1}$. It is the second largest Arctic river by annual discharge and the sixth largest globally. There are no dams on the mainstem of the Lena, but there is a dam on the Vilyuy River, one of the Lena's main tributaries (Holmes et al., 2013). The Lena's watershed is 2.6 million square kilometers, of which $70.5 \%$ is underlain by continuous permafrost (Juhls et al., 2020). Most of the water is discharged at the end of May and beginning of June when the ice in the rivers breaks up, but the Laptev Sea is still covered by sea ice (Holmes et al., 2012). The main Lena River branches enter the Buor-Khaya Bay through the northern and eastern part of the delta and through the Bykovskaya Channel with $20 \%-25 \%$ of the Lena River water discharge (Charkin et al., 2011). The further distribution of the river water in BuorKhaya Bay is mainly driven by the atmospheric systems of the cyclonic or anticyclonic Arctic circulation (Thibodeau et al., 2014; Wegner et al., 2013). 


\section{Material and methods}

\subsection{Study sites}

In the course of several expeditions to the Lena Delta (Siberia, Russia), we were able to repeatedly sample the same locations in winter and summer over the years (Table 1).

In September 2016, water samples were taken in the Bykovskaya Channel and mouth of the Lena River (Overduin et al., 2017). In April 2017 with ice cover on the water bodies, ice cores were taken at Lake Golzovoye, the Lena River, and Tiksi Bay, and the water below the ice was also sampled. Lake Golzovoye is an oval-shaped thermokarst lake about $0.5 \mathrm{~km}$ in diameter with a maximal depth of $10 \mathrm{~m}$, surrounded by yedoma uplands at various stages of degradation and with no ice grounding in its center (Spangenberg, 2018; Strauss et al., 2018). Tiksi Bay is a shallow brackish bay at the southern end of Buor-Khaya Bay but still strongly influenced by the Lena River outflow. The water column is usually stratified, with a colder, more saline water underlying the brackish surface layer (Overduin et al., 2016). The water of the Lena River was sampled near Samoylov island (main channel). In July and August 2017, we sampled the same locations (Lena River near Samoylov, Tiksi Bay, and Lake Golzovoye) with open water (Strauss et al., 2018). The transect to the "outer" Tiksi Bay has been investigated repeatedly over the previous years (Bussmann, 2013; Bussmann et al., 2017). In April 2018, again under-ice samples were taken from the Lena River (Kruse et al., 2019).

\subsection{Water sampling for methane analysis}

In winter, water samples at the ice-water interface were taken with a $1 \mathrm{~L}$ water sampler (Uwitec Austria) and transferred to $0.5 \mathrm{~L}$ Nalgene bottles. In the field camp, the water was transferred with a $60 \mathrm{~mL}$ syringe into glass bottles, closed with butyl stoppers and crimps, poisoned with $0.2 \mathrm{~mL} 25 \%$ $\mathrm{H}_{2} \mathrm{SO}_{4}$, and stored upside down at $4{ }^{\circ} \mathrm{C}$. In summer the water samples were directly transferred from the water sampler into the glass bottles and further processed as described above.

In winter 2017, due to problems of freezing, $40 \mathrm{~mL}$ of sample water was shaken for $2 \mathrm{~min}$ with $20 \mathrm{~mL}$ nitrogen in a $60 \mathrm{~mL}$ syringe. This headspace was then transferred into glass bottles filled with a saturated $\mathrm{NaCl}$ solution. Comparative measurements showed no significant difference between these two sampling strategies (Triputra, 2018). This data set has been published already: https://doi.org/10.1594/PANGAEA.905776 .

\subsection{Ice cores}

In winter 2017, in addition to water sampling, we also investigated ice cores for their methane content and methane oxidation rates. For each station three ice cores were drilled with a Kovacs Mark II ice coring system $(9 \mathrm{~cm}$ diameter). One core was used to measure the in situ temperature and backup, one core was used for methane analysis, and the third core was drilled for later molecular analyses. For determining the methane oxidation rates and later methane concentrations, the ice cores were processed at the Research Station Samoylov Island. The top $10 \mathrm{~cm}$, a $10 \mathrm{~cm}$ mid-section, and three $10 \mathrm{~cm}$ sections at the bottom of the core were cut off and transferred to special PVDF gas sampling bags (Keika Ventures). The remaining parts of the cores were kept frozen. The bags were evacuated and the cores melted within approx. $5 \mathrm{~h}$ in a water bath at $8^{\circ} \mathrm{C}$. The sample was distributed with a $60 \mathrm{~mL}$ syringe to three glass bottles for determination of MOX and one bottle (which was poisoned immediately with $\mathrm{H}_{2} \mathrm{SO}_{4}$ ) for analysis of methane concentration (Strauss et al., 2018).

\subsection{Methane analysis}

Methane concentrations were determined via the headspace method by adding $20 \mathrm{~mL}$ of $\mathrm{N}_{2}$ as headspace and vigorous shaking for $2 \mathrm{~min}$. Headspace methane concentrations were analyzed in the home laboratory with a gas chromatograph (GC 2014, Shimadzu) equipped with a flame ionization detector and a ShinCarbon column (Restek, USA). The temperatures of the oven, the injector, and detector were 100 , 120 , and $160^{\circ} \mathrm{C}$, respectively. The carrier gas $\left(\mathrm{N}_{2}\right)$ flow was $20 \mathrm{~mL} \mathrm{~min}^{-1}$, with 40 and $400 \mathrm{~mL} \mathrm{~min}^{-1}$ synthetic air. Gas standards (Air Liquide) with methane concentrations of 10 and $100 \mathrm{ppm}$ were used for calibration. The calculation of the methane concentration was performed according to Magen et al. (2014). The precision of the calibration line was $r^{2}=0.99$ and the reproducibility of the samples was $<5 \%$.

\subsection{Methane oxidation rate (MOX)}

The MOX rate was determined by adding radioactive tritiated methane to triplicate samples (Bussmann et al., 2015). The principle of the MOX rate determination is based on the ratio of produced tritiated hydrogen from the added tritiated methane. This ratio corrected for the incubation time gives the fractional turnover rate $\left(k^{\prime}, \mathrm{d}^{-1}\right)$. To obtain the MOX rate, $k^{\prime}$ is multiplied with the in situ methane concentration. Radioactive tritiated methane $\left(0.1 \mathrm{~mL}\right.$ of ${ }^{3} \mathrm{H}-$ methane, $2 \mathrm{kBq} \mathrm{mL}^{-1}$, American Radiolabeled Chemicals) was added to triplicate samples. Samples were incubated for $60 \mathrm{~h}$ at $1{ }^{\circ} \mathrm{C}$, in the dark. Incubation was stopped by adding $0.2 \mathrm{~mL}$ of $25 \% \mathrm{H}_{2} \mathrm{SO}_{4}$. Abiotic controls were poisoned before adding the tracer. Radioactivity was determined with a liquid scintillation counter (Triathler, Finland) and Ultima Gold (PerkinElmer) as a scintillation cocktail. For MOX, the limit of detection was calculated as described in Bussmann et al. (2015) and was determined to be $0.009 \mathrm{nmol} \mathrm{L}^{-1} \mathrm{~d}^{-1}$ for this data set.

In a set of experiments, we also assessed the influence of temperature on the MOX rate. Water samples (main chan- 
Table 1. Locations and sampling dates of water samples and ice cores for dissolved methane (M-conc) and methane oxidation rates (MOX).

\begin{tabular}{lllrrl}
\hline Location & Sampling date & Season & $\begin{array}{r}\text { Water } \\
\text { temperature } \\
\left({ }^{\circ} \mathrm{C}\right)\end{array}$ & $\begin{array}{r}\text { Number of } \\
\text { samples }\end{array}$ & sampling \\
\hline Lena River & 7-8 Sep 2016 & Summer & $8.5-10.3$ & 22 & M-conc \\
Lena River & 19-22 Apr 2017 & Winter & 1.3 & 6 & M-conc, MOX \\
Lena River & 29 Jul 2017 & Summer & $1-14$ & 13 & M-conc \\
Lena River & 21-24 Apr 2018 & Winter & -0.7 & 10 & M-conc \\
Lake Golzovoye & 7-8 Apr 2017 & Winter & 0.3 & 8 & M-conc \\
Lake Golzovoye & 7-8 Apr 2017 & Ice cores & & 5 & M-conc, MOX \\
Lake Golzovoye & 5 Aug 2017 & Summer & $7-10$ & 5 & M-conc \\
Tiksi Bay & 10 Apr 2017 & Winter & 0.3 & 2 & M-conc \\
Tiksi Bay & 10 Apr 2017 & Ice cores & & 4 & M-conc, MOX \\
Tiksi Bay & 15 Jul-5 Aug 2017 & Summer & $4-11$ & 6 & M-conc \\
\hline
\end{tabular}

nel, April 2017) that were incubated at temperatures from 1 , 4,7 , and $10^{\circ} \mathrm{C}$ show the temperature curve of the MOX reaction. At a previous cruise off Svalbard, identical experiments were performed (Mau et al., 2017a) with water from stations HE449-CTD-2, 10, 33, and 37 incubated at temperatures from $0,4,8,13$, and $20^{\circ} \mathrm{C}$. We determined the $Q_{10}$ factor, which indicates the temperature dependence of a biological process according to (Raven and Geider, 1988)

$Q_{10}=\exp \left(-10 \cdot \frac{m}{T_{\text {is }}^{2}}\right)$,

where $T_{\text {is }}$ is the in situ temperature and " $m$ " the slope of the regression line of the Arrhenius plot (the inverse of the absolute temperature vs. the natural logarithm of the MOX rate).

\subsection{Hydrochemistry and hydrology}

Profiles of water temperature and conductivity were measured with a CastAway CTD (SonTek) in summer 2016 and in winter and summer 2017. Water depth measurements were made with an echo-sounding device (Garmin), every $10 \mathrm{~m}$ along the profile. Water velocity was measured in three horizons at each vertical profile: $0.2,0.6$, and $0.8 \mathrm{H}$ (with $H$ being total water depth) using a hydrological speed recorder (GR-21). Water discharges were calculated according to the recommendations for Russian hydrometeorological stations (Fedorova et al., 2015).

\section{Results}

\subsection{Methane concentrations and hydrochemistry}

In the Lena River in summer 2016, median methane concentrations were $37 \mathrm{nM}(n=21)$ in surface water and significantly higher than the winter concentrations of 2017 (8 nM, Wilcoxon test, $p=0.0004$, Fig. 2). Comparing the summer and winter concentrations for 2017/18 also showed significantly higher values in summer, with a median of $25 \mathrm{nM}$ vs. $10 \mathrm{nM}$ in winter (Wilcoxon test, $p=0.0009$, Fig. 2). Pooling the complete data set into winter and summer data for the Lena River showed that summer concentrations were significantly higher than winter concentrations (median of $31 \mathrm{nM}$ vs. $8 \mathrm{nM}, p<0.001)$. In summer 2016, water temperature ranged from $8.5-10.3{ }^{\circ} \mathrm{C}$ and electric conductivity from $135-185 \mu \mathrm{S} \mathrm{cm}^{-1}$ with a $\mathrm{pH}$ value around 6 that showed almost no variation in the water columns of 8.3 to $10 \mathrm{~m}$ (Matthias Winkel, unpublished data).

In winter 2017, the water column under the ice of the Lena River was about $1.3^{\circ} \mathrm{C}$ with a conductivity of $275 \mu \mathrm{S} \mathrm{cm}^{-1}$; no stratification was evident. The water was flowing at a speed of $0.043 \mathrm{~m} \mathrm{~s}^{-1}$ under the ice and with $0.1 \mathrm{~m} \mathrm{~s}^{-1}$ above the bottom $(0.85 H)$ (Strauss et al., 2018) (Sect. 2.5). In the main channel of the Lena River the maximal water depth in winter 2017 was $25.3 \mathrm{~m}$ vs. $28 \mathrm{~m}$ in summer at the same point. In winter the water velocity in the channels is much lower than in summer: in April 2017 it was $0.18 \mathrm{~m} \mathrm{~s}^{-1}$ in the Bykovskaya Channel but reached $1.53 \mathrm{~m} \mathrm{~s}^{-1}$ in summer 2016.

In summer 2017, the water discharge in Bykovskaya Channel was $5313.4 \mathrm{~m}^{3} \mathrm{~s}^{-1}$. Water temperature ranged from $13-14{ }^{\circ} \mathrm{C}$ with no changes with water depth, indicating a full mixing (Strauss et al., 2018). In winter 2018, the water column under the ice of the Lena River was about $-0.7^{\circ} \mathrm{C}$ with a median conductivity of $465 \mu \mathrm{S} \mathrm{cm}^{-1}$ and a median $\mathrm{pH}$ of 7.3. In Bykovskaya Channel oxygen saturation had a median value of $51 \%$. No stratification of the water column was evident, based on water temperature and conductivity (Kruse et al., 2019). These findings agree to the Lena River monitoring observations by Juhls et al. (2020).

In Lake Golzovoye, in summer 2017, the median methane concentration was $49 \mathrm{nM}(n=5)$, while in winter concentrations were about 40 times higher with a median of $1957 \mathrm{nM}$ ( $n=8$, Wilcoxon test, $p=0.002$, Fig. 2). In winter, the water temperature of the lake was cold at the surface (median $0.3^{\circ} \mathrm{C}$ in the top $\left.1 \mathrm{~m}\right)$ and warmer $\left(2^{\circ} \mathrm{C}\right)$ at the bottom with a 


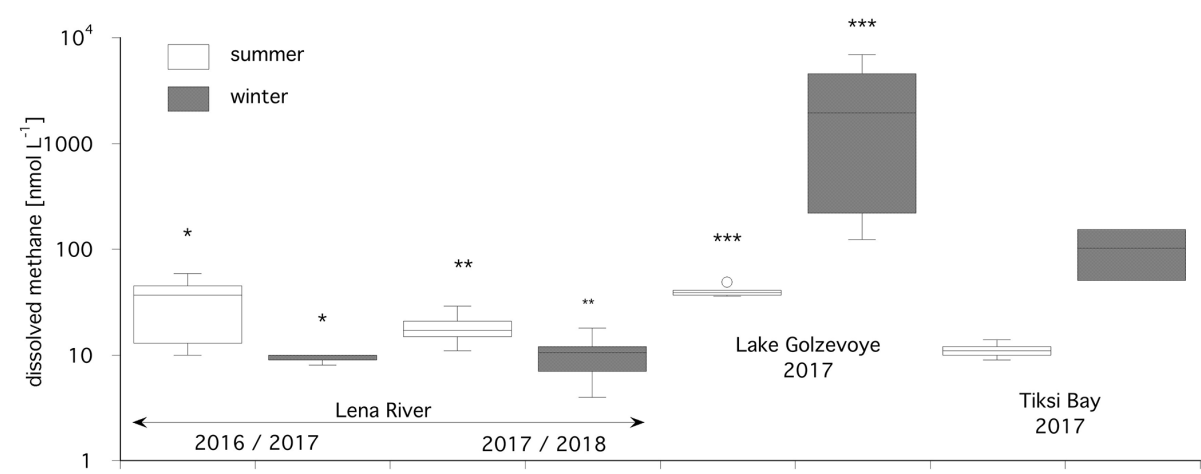

Figure 2. Median summer and winter methane concentrations at the Lena River, Lake Golzovoye, and Tiksi Bay in the years 2016-2018. Bright columns indicate summer values, and dark columns indicate winter values. The asterisks indicate significant differences between summer and winter data.

thermocline at $2 \mathrm{~m}$. In summer, the surface water was heated to $7-10^{\circ} \mathrm{C}$, while the bottom water only warmed to $4-5^{\circ} \mathrm{C}$.

In Tiksi Bay and in summer 2017, the median methane concentration was $14 \mathrm{nM}(n=6)$. In contrast, in winter concentrations were about 7 times higher with a median of $103 \mathrm{nM}(n=2)$. Due to low sample numbers, no statistical test was possible. In summer 2017, water temperature ranged from $4.3-10.9^{\circ} \mathrm{C}$ and electric conductivity from 20 $6200 \mu \mathrm{S} \mathrm{cm}^{-1}$. In winter, bottom water had a temperature of 3.3 and $0.3^{\circ} \mathrm{C}$ at the top $1 \mathrm{~m}$, with a thermocline at $1-2 \mathrm{~m}$.

\subsection{Ice cores}

Ice cores were taken at Lake Golzovoye and in Tiksi Bay, whereas no ice core data are available for the Lena River itself (Strauss et al., 2018). Methane concentrations in the ice cores of Lake Golzovoye and Tiksi Bay were rather low (both with a median of $9 \mathrm{nM}$ ). No depth gradients from the ice surface, middle section, and the three lowermost sections were evident. In a closeup for the bottom layers, there was a slight increase in methane towards the ice-water interface for the ice cores from Lake Golzovoye, but not from Tiksi Bay.

Figure 3 shows the median methane concentrations in the ice cores and in the water from the ice-water interface. Water column concentrations were 11 times and 109 times higher than in the ice cores, for Tiksi Bay and Lake Golzovoye, respectively, with a median of 102 and $985 \mathrm{nM}$ (Bussmann and Fedorova, 2019). However, in one core of Lake Golzovoye (core no. 24), concentrations were orders of magnitude higher throughout the core (854-11091 nM) and $6954 \mathrm{nM}$ in the water below Fig. 2 (Fig. 3).

\subsection{Methane oxidation rates (MOX)}

Methane oxidation rates were determined in the melted water from the ice cores from the different locations and in water from the Lena River. Due to logistic restraints at the field sites, no direct measurements of MOX in the waters of Lake

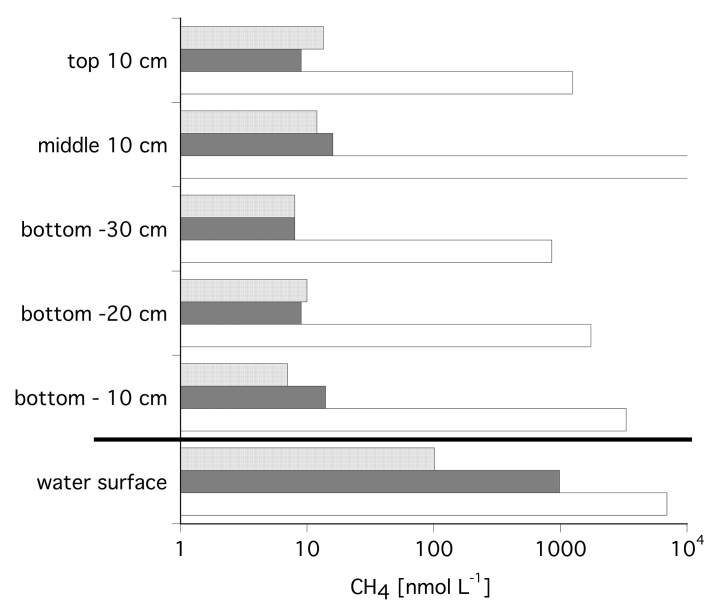

Figure 3. Median methane concentrations in the ice cores and in the water below the ice. Data from Tiksi Bay are shown in light grey and data for Lake Golzovoye in dark grey, with core no. 24 shown separately in white. Note the logarithmic scale.

Golzovoye and Tiksi Bay were possible. In the first step we determined the fractional turnover rate $k^{\prime}$. In the ice cores, $k^{\prime}$ was very patchily distributed, and $73 \%$ of all samples were below the detection limit. In all positive samples, the value for $k^{\prime}$ was rather stable with a median of 0.003 per day $(n=31)$. In the water samples below the ice, the fractional turnover rate $k^{\prime}$ was never below the detection limit. The median $k^{\prime}$ determined for all water samples (Lena River) was also $0.003(n=14)$. To calculate the MOX for all water samples, we multiplied the median $k^{\prime}$ of 0.003 obtained from Lena River and ice cores with the respective in situ methane concentration of the water columns of Lake Golzovoye, Tiksi Bay, and Lena River.

The highest MOX rates were found in the water below station 24 in Lake Golzovoye $\left(20.36 \mathrm{nmol} \mathrm{L}^{-1} \mathrm{~d}^{-1}\right)$, where very high methane concentrations were also observed (Fig. 4). The median MOX in the other water samples of Lake Golzovoye was about 1 order of magnitude lower 


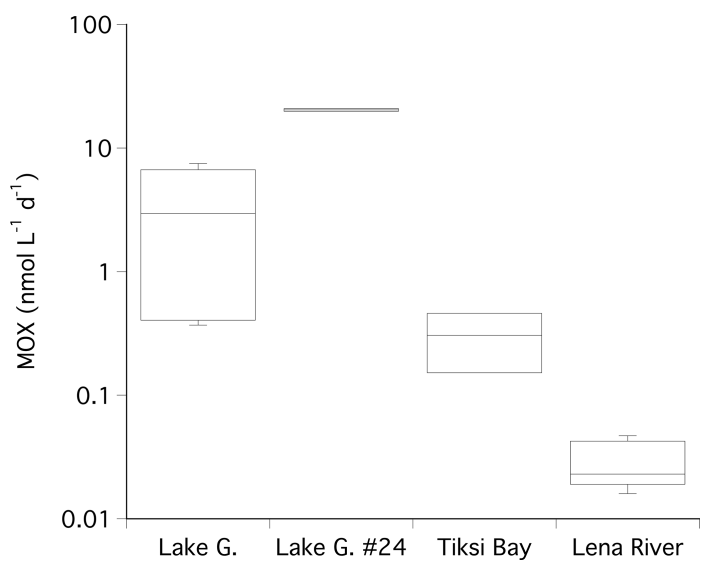

Figure 4. Box plot of the calculated methane oxidation rates (MOX) in water under ice cover at Lake Golzovoye, at the location of ice core no. 24, Tiksi Bay, and the Lena River. Note the logarithmic scale.

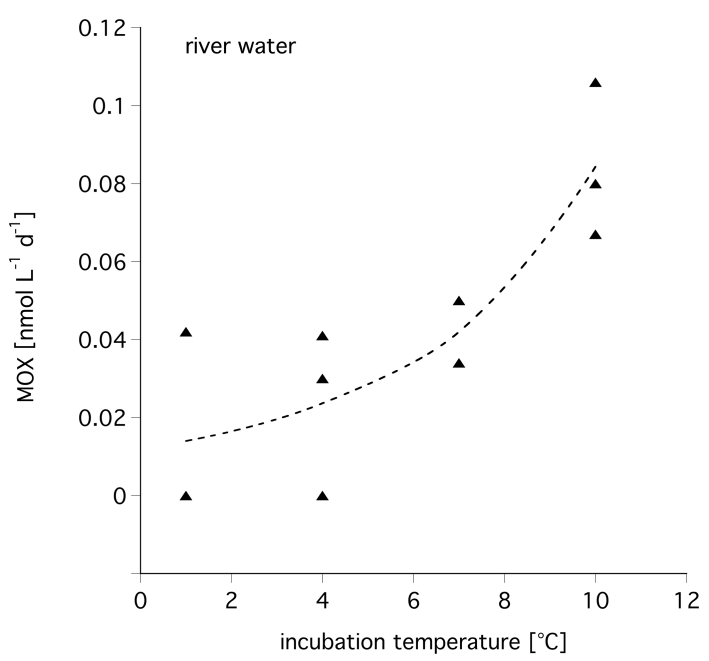

Figure 5. Influence of incubation temperature on methane oxidation rate for Lena River water, winter 2017.

$\left(2.95 \mathrm{nmol} \mathrm{L}^{-1} \mathrm{~d}^{-1}\right)$. In Tiksi Bay and in the Lena River MOX rates decreased by further orders of magnitude (median of 0.305 and $0.023 \mathrm{nmol} \mathrm{L}^{-1} \mathrm{~d}^{-1}$, Fig. 4).

\subsection{Temperature influence on MOX}

To assess the influence of temperature on the MOX, we incubated water samples at different temperatures and determined their MOX rate. As expected, with increasing temperature the MOX rate also increased (Fig. 5). The $Q_{10}$ calculated for these water samples from the Lena River was $2.72 \pm 0.69$. For polar and marine waters off Svalbard a $Q_{10}$ of $2.99 \pm 0.86$ was calculated.

\section{Discussion}

\subsection{Methane concentrations and hydrochemistry}

In this study we compared the methane concentration under ice cover (winter) with open-water situations (summer) in three different water bodies.

In winter the methane concentrations in the Lena River were 4 times lower than in summer (Table 2). The Lena River displays a reduced but still substantial water flow/discharge under ice cover. In 2017, the discharge in winter (March and April with 2830 and $2185 \mathrm{~m}^{3} \mathrm{~s}^{-1}$ ) was about 10 times lower than in summer (July and August with 29800 and $26000 \mathrm{~m}^{3} \mathrm{~s}^{-1}$ (Shiklomanov et al., 2018).

In winter there are only a few possible sources of methane left. The surrounding soils of the drainage basins are all frozen. The ground below the main channels of the Lena is still unfrozen (Fedorova et al., 2019); however the sediment consists of coarse grain sizes and is poor in organic material (Rivera et al., 2006), and we do not expect any in situ methane production. Especially in the Lena River, a substantial amount of particulate organic carbon (POC) originates from thermokarst-induced, abrupt collapse of Pleistocene Ice Complex deposits. These events mainly occur in late summer. The signal however is still visible in winter (Wild et al., 2019). With these collapses methane could also be imported to the river. So, we could only detect low methane concentrations in winter. In contrast, in summer, the active-layer soils from the drainage basin allow for several sources of methane and thus increased methane concentrations in summer. Also, methane could be transported from the southern Lena catchment towards our study area, as is suggested for particulate organic matter (Winterfeld et al., 2015). At least during the warm season, methane production from (temperate) river sediments is possible (Bednařík et al., 2019).

In Tiksi Bay, we observed an increase of a factor of 7 in dissolved methane under ice cover, compared to open-water conditions (Table 2). Tiksi Bay is part of Buor-Khaya Bay and via the central Laptev Sea perennially connected to the Arctic Ocean. Not much is known about tidal surge or water movement in Tiksi Bay under ice cover. It is anticipated that the ice cover on Tiksi Bay will lead to a decrease in tidal amplitudes and velocities (Fofonova et al., 2014). The structure of ice formation in Tiksi Bay also suggests that even in winter it is still an open system connected to the outer bay (Spangenberg et al., 2020). Sources of methane could be through diffusion of methane from the underlying sediment (Bussmann et al., 2017), where methane is produced by the degradation of organic material. However, as aerobic methane oxidation in the water column is impaired by low temperatures, methane concentrations in water increase.

In Lake Golzovoye, dissolved methane concentrations increased by a factor of 40 from summer to winter (Table 2). Lake Golzovoye is an isolated freshwater lake with presumably only a weak thermohaline circulation (Leppäranta, 
Table 2. Comparison of methane concentration in water and ice as well as methane oxidation rates (MOX) at different sites and in different seasons.

\begin{tabular}{|c|c|c|c|c|c|}
\hline Location & $\begin{array}{l}{\left[\mathrm{CH}_{4}\right] \text { winter / }} \\
{\left[\mathrm{CH}_{4}\right] \text { summer }^{\mathrm{a}}}\end{array}$ & $\begin{array}{l}\text { Under ice } \\
\text { accumulation }^{b}\end{array}$ & $\begin{array}{l}\text { Water } \\
\text { velocity } \\
\text { winter }\end{array}$ & $\begin{array}{l}{[\mathrm{MOX}]} \\
\text { winter }^{\mathrm{c}}\end{array}$ & $\begin{array}{l}\text { MOX }_{\text {during ice off }} / \\
\text { MOX during ice coverage }^{\mathrm{d}}\end{array}$ \\
\hline Lena River & $S>W, \times 5$ & $\mathrm{NA}^{\mathrm{e}}$ & strong & $\begin{array}{l}\text { Low, } \\
S \gg W\end{array}$ & $\begin{array}{l}4674 / 4 \mathrm{nmol} \mathrm{L}^{-1} \\
=1270\end{array}$ \\
\hline $\begin{array}{l}\text { Lake } \\
\text { Golzovoye }\end{array}$ & $W>S, \times 40$ & $W_{\mathrm{a}} \gg I, \times 109$ & minor & $\begin{array}{l}\text { High, } \\
S>W\end{array}$ & $\begin{array}{l}10165 / 797 \mathrm{nmol} \mathrm{L}^{-1} \\
=13\end{array}$ \\
\hline Tiksi Bay & $W>S, \times 7$ & $W_{\mathrm{a}}>I, \times 11$ & medium & $\begin{array}{l}\text { Medium } \\
S=W\end{array}$ & $\begin{array}{l}40 / 84 \mathrm{nmol} \mathrm{L}^{-1} \\
=0.5\end{array}$ \\
\hline
\end{tabular}

2015; Spangenberg et al., 2020). A similar seasonal pattern of methane among lake waters of the Mackenzie Delta has been observed, ranging from very high concentrations at the end of winter beneath lake ice $(>2000000 \mathrm{nM})$ to considerably lower concentrations during open water, particularly by late summer (approx. $10000 \mathrm{nM}$ ) (Cunada et al., 2018). For yedoma lakes in Alaska, the same pattern was observed with high methane concentrations in winter and a decrease of more than 1 order of magnitude in summer (even though the actual concentrations $>7.53 \mathrm{mg} \mathrm{L}^{-1}$ or $120 \mathrm{mM}$ were much higher than in this study) (Martinez-Cruz et al., 2015; Sepulveda-Jauregui et al., 2015). The same pattern is reported for boreal Swedish lakes (Denfeld et al., 2018). The source of methane in the water column of Lake Golzovoye is presumably the sediment, where high concentrations and active methane production, sulfate reduction, and anaerobic methane oxidation have been observed in winter 2017 (Liebner et al., 2021).

The role of water velocity and water column mixing is not clear, but our data suggest more methane accumulates under ice in a stagnant water body such as a lake than in a water body with running water such as a river. Water column turbulent diffusivity has a major influence on the methane cycle, where higher turbulence potentially leads to a greater proportion of methane being oxidized, and lower turbulence leads to a greater proportion being stored (Vachon et al., 2019).

\subsection{Ice cores}

The median methane concentration of all ice cores for Lake Golzovoye and Tiksi Bay was $9 \mathrm{nM}$, which was supersaturated compared to atmospheric concentrations, for which the equilibrium concentration would be $5 \mathrm{nM}$. More details on the ice formation in the different water bodies are given in Spangenberg et al. (2020). Compared to the methane concentrations in the water, the concentrations in the ice were 1-2 orders of magnitude lower (Table 2). This means that, in terms of methane, a complete separation of the water body from the atmosphere can be assumed. As mentioned earlier in this study and in Spangenberg et al. (2020), core no. 24 (LK3 ) in Lake Golzovoye had much higher methane concentrations throughout the core and visible inclusions of (methane) bubbles. We assume that core no. 24 was located above an active ebullition site, which might have slowed ice formation and prolonged direct methane release to the atmosphere.

In the ice itself, $28 \%$ of the samples showed methane oxidation capability. During ice formation most free-living bacteria are lost from the liquid phase through incorporation into the ice, while bacterial aggregates remain in the water (Santibáñez et al., 2019). In an experimental setup, Wilson et al. (2012) show that multiple freeze-thaw cycles in water from freshwater lakes reduce the total bacterial cell number at least 100000 -fold. In addition, methanotrophic bacteria are particular sensitive to freezing and thawing (Green and Woodford, 1992; Hoefman et al., 2012). These findings could explain the reduced activity of methanotrophic bacteria within the ice cores.

Also, we did not detect any discoloration or other indications of photosynthesis or other biological processes in the bottom layer of the ice cores. Thus, we conclude that the ecosystem of freshwater ice and its lower margin does not reach the richness observed in polar sea ice (Leppäranta, 2015).

\subsection{Methane oxidation rates (MOX)}

In this study we determined the methane oxidation rate with tritiated methane as a tracer. The advantage of the tracer injection method is that natural low concentrations are hardly altered, and thus we assume that our values are close to the actual rates. The fractional turnover rate $k^{\prime}$ was determined in ice cores from the lake and Tiksi Bay and in river water, but not for water samples from the lake and Tiksi Bay. Within these locations $k^{\prime}$ was evenly distributed. However, 
$k^{\prime}$ may vary between different environments (river, lake, and brackish water) as well as between ice cores and underlying water. The fractional turnover rate is influenced by temperature, methane, and oxygen concentrations (Steinle et al., 2017). Temperature was low at all locations and should not have a big impact on $k^{\prime}$. For methane concentrations ranging from 6-800 nM, $k^{\prime}$ was independent from the methane concentration. Studies from Mau et al. (2017b) and Steinle et al. (2017) support the fact that the $k$-to-methane relation does not necessarily apply. However, it cannot be excluded that at the very high methane concentration in Lake Golzovoye the real $k^{\prime}$ may have been larger. Thus, at very high methane concentrations, our estimations of MOX would be an underestimation of the real rates and real $k^{\prime}$. For all other samples, we suppose that the application of one $k^{\prime}$ to all samples is the best possible assumption.

Our data span 3 orders of magnitude, ranging from $0.02 \mathrm{nmol} \mathrm{L}^{-1} \mathrm{~d}^{-1}$ in the Lena River to 0.31 in Tiksi Bay and $2.95 \mathrm{nmol} \mathrm{L}^{-1} \mathrm{~d}^{-1}$ in Lake Golzovoye. Another polar study finds a MOX of $0.004-1.09 \mathrm{mg} \mathrm{C} \mathrm{m}^{-3} \mathrm{~d}^{-1}(=0.33-$ $\left.91 \mathrm{nmol} \mathrm{L}^{-1} \mathrm{~d}^{-1}\right)$ at the water-ice interface of a Swedish lake (Ricão Canelhas et al., 2016). Also, Bastviken et al. (2002) report a MOX of similar range $\left(0.001-39 \mathrm{mg} \mathrm{C} \mathrm{m}^{-3} \mathrm{~d}^{-1}=\right.$ $\left.0.08-3250 \mathrm{nmol} \mathrm{L}^{-1} \mathrm{~d}^{-1}\right)$. However, the methods of determining MOX were quite different and more of a potential rate. Another study in yedoma lakes in Alaska also reports higher MOX (0.03-0.28 mg methane $\mathrm{L}^{-1} \mathrm{~d}^{-1}=1875-$ $17500 \mathrm{nmol} \mathrm{L}^{-1} \mathrm{~d}^{-1}$ ) with a kinetic approach to determine MOX (Martinez-Cruz et al., 2015). In marine polar waters off Svalbard MOX was determined with the same tracer method and ranged from 1.6-2.2 $\mathrm{nmol} \mathrm{L}^{-1} \mathrm{~d}^{-1}$ in summer (Mau et al., 2017a). Thus, our data are within the very low range of reported MOX rates in polar regions, probably due to methodological differences.

In previous years we determined MOX in the study area during summer, applying the same method as in this study. Therefore, we can approach a seasonal comparison (winter vs. summer), assuming interannual variability is negligible and neglecting spring and autumn mixing. To estimate the importance of ice cover on the overall MOX, we assume an ice coverage of $270 \mathrm{~d}$ for Lake Golzovoye and Tiksi Bay (Cortés and MacIntyre, 2020) and $160 \mathrm{~d}$ for the Lena River (Shiklomanov and Lammers, 2014). By multiplying the respective winter and summer MOX with the days of ice cover and days of open water, we can calculate the amount of methane oxidized during ice cover versus ice-off time.

For the Lena River and permafrost lakes, we compare our winter data with summer data obtained in July 2012 (Osudar et al., 2016). For the Lena River, with a median MOX of $22.8 \mathrm{nmol} \mathrm{L}^{-1} \mathrm{~d}^{-1}(n=8)$, the summer MOX was about 3 orders of magnitude higher than in winter $\left(0.023 \mathrm{nmol} \mathrm{L}^{-1} \mathrm{~d}^{-1}\right)$. The amount of methane oxidized during ice-off ( $\left.4674 \mathrm{nmol} \mathrm{L}^{-1}\right)$ was about 1270 times more than the amount oxidized during ice cover $\left(4 \mathrm{nmol} \mathrm{L}^{-1}\right)$.
For MOX in lakes, summer rates from small lakes near Research Station Samoylov Island were 36 times higher (median $107 \mathrm{nmol} \mathrm{L}^{-1} \mathrm{~d}^{-1}, n=6$ ) than winter rates $\left(2.95 \mathrm{nmol} \mathrm{L}^{-1} \mathrm{~d}^{-1}\right)$. Also, for yedoma lakes in Alaska, summer values of MOX were about 10 times higher than winter values (Martinez-Cruz et al., 2015). The amount of methane oxidized during open water $\left(10165 \mathrm{nmol} \mathrm{L}^{-1}\right)$ was about 13 times more than the amount oxidized during ice cover (797 $\mathrm{nmol} \mathrm{L}^{-1}$ ).

For Tiksi Bay there are also summer values of MOX available (Bussmann et al., 2017). However, with a median summer rate of $0.419 \mathrm{nmol} \mathrm{L}^{-1} \mathrm{~d}^{-1}$ for surface riverine water, there is little difference when compared to our winter data $\left(0.31 \mathrm{nmol} \mathrm{L}^{-1} \mathrm{~d}^{-1}\right.$, Table 2$)$. The amount of methane oxidized during open water $\left(40 \mathrm{nmol} \mathrm{L}^{-1}\right)$ was about 2 times less than the amount oxidized during ice cover (84 $\mathrm{nmol} \mathrm{L}^{-1}$ ).

There still seems to be no clear consensus on the factors limiting MOX in winter. In several boreal lakes MOX was restricted to lakes where the phosphate concentrations were highest (Denfeld et al., 2016). Another study reports that in winter MOX is mainly controlled by the dissolved oxygen concentration, while in the summer it was controlled primarily by the methane concentration (Martinez-Cruz et al., 2015). The stratification of lakes determines the availability of methane and oxygen for the methanotrophic bacteria and thus strongly influences MOX (Kankaala et al., 2006, 2007).

Temperature is also an important factor affecting winter MOX. MOX is observed at temperatures of $2{ }^{\circ} \mathrm{C}$, mostly by Methylococcaceae (Ricão Canelhas et al., 2016). A recent study with in situ concentrations in a northern temperate lake observes a $Q_{10}$ of $2.4 \pm 1.4$ (Thottathil et al., 2019), which is a bit lower than the $Q_{10}$ of this study with 2.7 and 2.9 for polar, fresh, and marine water, respectively. In addition, there are co-correlations between temperature and methane concentration. At substrate (methane) saturation, temperature has a strong influence, while under substrate-limiting conditions, temperature has a minor influence (Lofton et al., 2014; King and Adamsen, 1992). In contrast, Thottathil et al. (2019) observed a strong temperature response for MOX across the entire range of ambient methane concentrations. Measuring MOX with tritiated methane and thus at concentrations close to in situ, we can compare the $Q_{10}$ from this study with data from temperate environments. The $Q_{10}$ for polar environments was higher than $Q_{10}$ values obtained from temperate waters (the Elbe, Germany, and North Sea; Bussmann et al., 2015) with 1.52 and 1.75, respectively (Fig. 6). Although the substrate concentration in the temperate waters was higher, MOX from polar regions seems to react more sensitively to a temperature increase. One explanation could be that the temperature optimum of psychrotolerant methanotrophs is below $20^{\circ} \mathrm{C}$ (Bale et al., 2019). Thus, the polar methanotrophs are further away from their optimum temperature and react with increased activity to temperature increases while methanotrophic bacteria from temperate wa- 


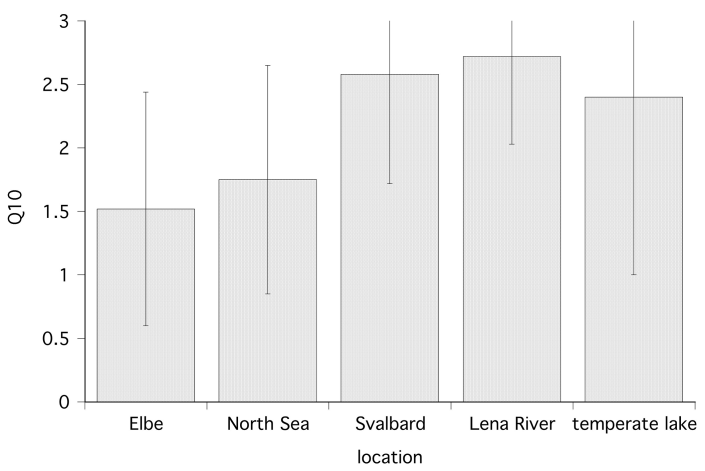

Figure 6. Temperature dependence $\left(Q_{10}\right)$ of the methane oxidation rate at different locations; shown are the mean and standard deviation. Data for the Elbe and North Sea are from Bussmann et al. (2015), and data for the temperate lake are from Thottathil et al. (2019).

ters are nearer to their optimum temperature and do not react as sensitively.

Environmental conditions between winter and summer conditions certainly differ and may also affect the population structure of methanotrophs. Some psychrophilic strains adapt to colder temperatures $\left(20^{\circ} \mathrm{C}\right.$ vs. $\left.4{ }^{\circ} \mathrm{C}\right)$ by modifying their fatty acid composition (Bale et al., 2019), while others may have only limited abilities, resulting in different population structures. This is supported by a recent study revealing that wintertime Arctic bacterial communities' and food webs' structure change based on carbon availability (Kellogg et al., 2019).

In this study we compared the methane inventory (concentrations) and the biological sink (methane oxidation) of three polar aquatic environments under summer and winter conditions. For a complete budget, the methane sources should be known, as there is methane input from the sediment, by either diffusion or ebullition and lateral input by groundwater, river flow, or water circulation in the bay. Additional sinks for the systems are methane flux from the water into the atmosphere and lateral output by water circulation. In the following we apply our results on the methane cycle of the three different environments.

In the river we find higher methane concentrations and higher MOX in summer. The low concentrations in winter are probably due to low methane input from the frozen borders and a reduced but still effective dilution of methane by the water flow (Fedorova et al., 2019). MOX is low and thus will not contribute to the removal of methane from the river. The ice-off on the river will probably not increase methane emissions, as only minor amounts are accumulated under the ice.

In the lake, we observed a strong accumulation of methane in winter under ice cover. Thus, either the methane sources are strengthened and/or the sinks have weakened. In winter there is an active cycle of methanogenesis and (anaerobic) methane oxidation in the sediment (Liebner et al., 2021). However, we assume that this activity is the same or less than in summer. Ebullition does occur in winter (as shown for ice core no. 24) and thus will lead to locally increased methane concentrations. The methane sink and flux from the water into the atmosphere is cut off by the ice cover; thus the only remaining sink is MOX, which is reduced by low temperature and other environmental factors as discussed above. During and after ice-off, altered or weakened water column stratification will allow a mixing of the water column. This results in increased methane emission but also enhanced MOX as more oxygen and nutrients will become available (Utsumi et al., 1998). In summer increased MOX and methane flux from the water lead to reduced methane concentrations in the water.

In the bay, we observed an accumulation of methane under ice and higher concentrations in winter. Thus, we assume that the sinks have weakened, with a stable or reduced methane input. Our comparison shows that MOX does not change significantly between the seasons; thus the other main sink, transport via water exchange of the bay with the shelf water, is reduced during winter because of the ice cover (Fofonova et al., 2014), and direct flux from open water is reduced by the ice cover. There is probably still an input of methane from the sediments, which results in a slight accumulation of methane. The ice-off in the bay will result in increased methane emissions and also reduced methane concentrations when water circulation in the bay restarts.

In a changing, warming Arctic, a shortened time of ice coverage on lakes and rivers is predicted (Prowse et al., 2011; Newton and Mullan, 2020; Benson et al., 2012). This could be $-6 \mathrm{~d}$ per $1^{\circ}$ of temperature increase (Newton and Mullan, 2020). Another scenario is given by Benson et al. (2012) with $-17 \mathrm{~d}$ every 100 years. For the lake we observed the greatest difference between the ice-covered winter situation and open water. Especially in the lake, the duration of ice cover is important and we assume that a shorter ice cover results in less high methane concentrations under ice and subsequently in a reduced pulse of methane emissions at ice-off. With respect to our study, this would imply a shortened time for methane accumulation under ice and a shortened time for the less efficient winter-MOX. For lakes this would result in increased MOX during ice-off with a ratio

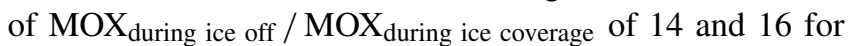
the two scenarios vs. 13 for today. For rivers the same trend can be assumed, with the ratio increasing from today's 1270 towards 1358 or 1539 for the two scenarios.

Thus, an extended time of ice-free conditions could reduce the methane emissions from Arctic water bodies. However, it has to be kept in mind that not much is known about the MOX during water column mixing in spring or autumn. 


\section{Conclusions}

Our work on an eastern Siberian lake, river, and marine bay showed that methane accumulates under ice cover during the winter and is consumed differently in the three water bodies. Our study was restricted to late winter and midsummer, which represent two extremes of the annual cycle. Other processes during autumn mixing, ice-on, and ice-off are not considered.

Two main physical factors affecting the methane cycle in the water bodies under ice cover are the water velocity and the ice cover itself. In most of our ice cores no concentration gradient between the bottom of the ice cores and the top was obvious. As we could hardly detect any MOX within the ice cores, we assume that methane is not integrated into the ice during freeze-up. Therefore, the ice cover seems to effectively prevent any methane flux from the highly accumulated methane concentrations in the water towards the atmosphere. In the river with running water under the ice cover, only a minor accumulation of methane was observed. In the bay with a restricted but still present water movement, dilution or mixing with other water bodies, allowed for a moderate accumulation of methane. In the small lake, we assume a stagnant water body with a subsequent accumulation of high amounts of methane.

The biotic counterpart of the observed methane accumulation is microbial methane oxidation (MOX). In most cases, MOX in summer was much higher than in winter. We observed a strong dependence of MOX on the temperature, and with in situ temperatures of only $1{ }^{\circ} \mathrm{C}$ in winter subsequently low rates were observed. Higher methane concentrations in winter indicate the methanotrophic bacteria were not limited by substrate (methane) concentrations. However, especially in Lake Golzovoye and its stagnant water body oxygen could become a limiting factor. Other factors could be nutrient limitation or shift in the population structure.

A shortened time of ice coverage on the water bodies is predicted with increasing temperatures in the Arctic. With respect to our study this would imply a shortened time for methane to accumulate below the ice and a shorter time for the less efficient winter MOX. Especially for lakes, an extended time of ice-free conditions could reduce the methane flux from the Arctic water bodies.

Data availability. Data on methane concentration and MOX are available at the PANGAEA database (https://doi.pangaea.de/ 10.1594/PANGAEA.920013 and https://doi.pangaea.de/10.1594/ PANGAEA.919986) (Bussmann et al., 2020a, b).

Author contributions. All authors carried out fieldwork and measurements and collected samples. IB performed the methane and MOX analyses. IB, BJ, PPO, and MW contributed to the initial and final versions of the paper.
Competing interests. The authors declare that they have no conflict of interest.

Acknowledgements. This study was part of the Helmholtz program PACES, Topic 1.3. We are thankful to the logistics department of the Alfred Wegener Institute, particularly Waldemar Schneider. Logistical support for the fieldwork was provided by the Russian Hydrographic Service (Hydrobase Tiksi).

Financial support. Matthias Winkel was supported by the Helmholtz Young Investigators Group of Susanne Liebner (VHNG-919) and further supported by the German Ministry of Education and Research by a grant to Dirk Wagner (03G0836D). We acknowledge support by the Open Access Publication Funds of Alfred-Wegener-Institut Helmholtz-Zentrum für Polar- und Meeresforschung.

The article processing charges for this open-access publication were covered by a Research Centre of the Helmholtz Association.

Review statement. This paper was edited by Zhongjun Jia and reviewed by two anonymous referees.

\section{References}

Angelopoulos, M., Westermann, S., Overduin, P., Faguet, A., Olenchenko, V., Grosse, G., and Grigoriev, M. N.: Heat and salt flow in subsea permafrost modeled with CryoGRID2, J. Geophys. Res.-Earth, 124, 920-937, https://doi.org/10.1029/2018JF004823, 2019.

Bale, N. J., Rijpstra, W. I. C., Sahonero-Canavesi, D. X., Oshkin, I. Y., Belova, S. E., Dedysh, S. N., and Sinninghe Damsté, J. S.: Fatty acid and hopanoid adaption to cold in the nethanotroph Methylovulum psychrotolerans, Front. Microbiol., 10, 589, https://doi.org/10.3389/fmicb.2019.00589, 2019.

Bastviken, D., Ejlertsson, J., Sundh, I., and Tranvik, L.: Measurement of methane oxidation in lakes: a comparison of methods, Environ. Sci. Technol., 36, 3354-3361, 2002.

Bastviken, D., Cole, J., Pace, M., and Tranvik, L.: Methane emissions from lakes: Dependence of lake characteristics, two regional assessments, and a global estimate, Global Biogeochem. Cy., 18, GB4009, https://doi.org/10.1029/2004GB002238, 2004.

Bednařík, A., Blaser, M., Matoušů, A., Tušer, M., Chaudhary, P. P., Šimek, K., and Rulík, M.: Sediment methane dynamics along the Elbe River, Limnologica, 79, 125716, https://doi.org/10.1016/j.limno.2019.125716, 2019.

Benson, B. J., Magnuson, J. J., Jensen, O. P., Card, V. M., Hodgkins, G., Korhonen, J., Livingstone, D. M., Stewart, K. M., Weyhenmeyer, G. A., and Granin, N. G.: Extreme events, trends, and variability in Northern Hemisphere lakeice phenology (1855-2005), Climatic Change, 112, 299-323, https://doi.org/10.1007/s10584-011-0212-8, 2012.

Biskaborn, B. K., Subetto, D. A., Savelieva, L. A., Vakhrameeva, P. S., Hansche, A., Herzschuh, U., Klemm, J., Heinecke, 
L., Pestryakova, L. A., Meyer, H., Kuhn, G., and Diekmann, B.: Late Quaternary vegetation and lake system dynamics in north-eastern Siberia: Implications for seasonal climate variability, Quaternary Sci. Rev., 147, 406-421, https://doi.org/10.1016/j.quascirev.2015.08.014, 2016.

Bussmann, I.: Distribution of methane in the Lena Delta and Buor Khaya Bay, Russia, Biogeosciences, 10, 4641-4465, https://doi.org/10.5194/bg-10-4641-2013, 2013.

Bussmann, I. and Fedorova, I.: Dissolved methane concentrations under ice cover in the Lena Delta area, PANGAEA, https://doi.org/10.1594/PANGAEA.905776, 2019.

Bussmann, I., Matousu, A., Osudar, R., and Mau, S.: Assessment of the radio ${ }^{3} \mathrm{H}-\mathrm{CH}_{4}$ tracer technique to measure aerobic methane oxidation in the water column, Limnol. Oceanogr.-Meth., 13, 312-327, https://doi.org/10.1002/lom3.10027, 2015.

Bussmann, I., Hackbusch, S., Schaal, P., and Wichels, A.: Methane distribution and oxidation around the Lena Delta in summer 2013, Biogeosciences, 14, 4985-5002, https://doi.org/10.5194/bg-14-4985-2017, 2017.

Bussmann, I. Fedorova, I., Juhls, B., Overduin, P. and Winkel, M.: Dissolved methane concentrations and oxidation rates in ice cores from the Lena Delta area, 2016-2018, PANGAEA, https://doi.pangaea.de/10.1594/PANGAEA.920013, 2020a.

Bussmann, I. Fedorova, I., Juhls, B., Overduin, P. and Winkel, M.: Dissolved methane concentrations and oxidation rates in water samples from the Lena Delta area, 2016-2018, PANGAEA, https://doi.pangaea.de/10.1594/PANGAEA.919986, 2020 b.

Charkin, A. N., Dudarev, O. V., Semiletov, I. P., Kruhmalev, A. V., Vonk, J. E., Sánchez-García, L., Karlsson, E., and Gustafsson, Ö.: Seasonal and interannual variability of sedimentation and organic matter distribution in the Buor-Khaya Gulf: the primary recipient of input from Lena River and coastal erosion in the southeast Laptev Sea, Biogeosciences, 8, 2581-2594, https://doi.org/10.5194/bg-8-2581-2011, 2011.

Cole, J. J., Prairie, Y. T., Caraco, N. F., McDowell, W. H., Tranvik, L. J., and Striegl, R. G.: Plumbing the global carbon cycle: Integrating inland waters into the terrestrial carbon budget, Ecosystems, 10, 172-185, https://doi.org/10.1007/s10021-006-9013-8, 2007.

Cortés, A. and MacIntyre, S.: Mixing processes in small arctic lakes during spring, Limnol. Oceanogr., 65, 260-288, https://doi.org/10.1002/lno.11296, 2020.

Cunada, C. L., Lesack, L. F. W., and Tank, S. E.: Seasonal dynamics of dissolved methane in lakes of the Mackenzie Delta and the role of carbon substrate quality, J. Geophys. Res.-Biogeo., 123, 591-609, https://doi.org/10.1002/2017JG004047, 2018.

DelSontro, T., McGinnis, D. F., Wehrli, B., and Ostrovsky, I.: Size does matter: Importance of large bubbles and small-scale hot spots for methane transport, Environ. Sci. Technol., 49, 12681276, https://doi.org/10.1021/es5054286, 2015.

Denfeld, B. A., Ricão Canelhas, M., Weyhenmeyer, G. A., Bertilsson, S., Eiler, A., and Bastviken, D.: Constraints on methane oxidation in ice-covered boreal lakes, J. Geophys. Res.-Biogeo., 121, 1924-1933, https://doi.org/10.1002/2016JG003382, 2016.

Denfeld, B. A., Klaus, M., Laudon, H., Sponseller, R. A., and Karlsson, J.: Carbon dioxide and methane dynamics in a small boreallake during winter and spring melt events, J. Geophys. Res.-Biogeo., 123, 2527-2540, https://doi.org/10.1029/2018JG004622, 2018.
Deshpande, B. N., MacIntyre, S., Matveev, A., and Vincent, W. F.: Oxygen dynamics in permafrost thaw lakes: Anaerobic bioreactors in the Canadian subarctic, Limnol. Oceanogr., 60, 16561670, https://doi.org/10.1002/lno.10126, 2015.

Fedorova, I., Chetverova, A., Bolshiyanov, D., Makarov, A., Boike, J., Heim, B., Morgenstern, A., Overduin, P. P., Wegner, C., Kashina, V., Eulenburg, A., Dobrotina, E., and Sidorina, I.: Lena Delta hydrology and geochemistry: long-term hydrological data and recent field observations, Biogeosciences, 12, 345-363, https://doi.org/10.5194/bg-12-345-2015, 2015.

Fedorova, I., Bobrov, N., Pankova, D., Konosavskii, P., and Alekseeva, N.: Modeling of thermic process of the arctic ecosystems, in: International Multidisciplinary Scientific GeoConference Surveying Geology and Mining Ecology Management, SGEM, 30 June-6 July 2019, Albena, Bulgaria, 401-409, 2019.

Fisher, R. E., Sriskantharajah, S., Lowry, D., Lanoisellé, M., Fowler, C. M. R., James, R. H., Hermansen, O., Lund Myhre, C., Stohl, A., Greinert, J., Nisbet-Jones, P. B. R., Mienert, J., and Nisbet, E. G.: Arctic methane sources: Isotopic evidence for atmospheric inputs, Geophys. Res. Lett., 38, L21803, https://doi.org/10.1029/2011g1049319, 2011.

Fofonova, V., Androsov, A., Danilov, S., Janout, M., Sofina, E., and Wiltshire, K.: Semidiurnal tides in the Laptev Sea Shelf zone in the summer season, Cont. Shelf Res., 73, 119-132, https://doi.org/10.1016/j.csr.2013.11.010, 2014.

Green, P. N. and Woodford, S. K.: Preservation studies on some obligatory methanotrophic bacteria, Lett. Appl. Microbiol., 14, 158-162, 1992.

Günther, F., Overduin, P. P., Yakshina, I. A., Opel, T., Baranskaya, A. V., and Grigoriev, M. N.: Observing Muostakh disappear: permafrost thaw subsidence and erosion of a ground-ice-rich island in response to arctic summer warming and sea ice reduction, The Cryosphere, 9, 151-178, https://doi.org/10.5194/tc-9-151-2015, 2015.

Gurevich, E. V.: Influence of air temperature on the river runoff in winter (the Aldan river catchment study), Russ. Meteorol. Hydrol., 34, 628-633, 2009.

Hoefman, S., Van Hoorde, K., Boon, N., Vandamme, P., De Vos, P., and Heylen, K.: Survival orrevival: Long-term preservation induces a reversible viable but non-culturable state in methane-oxidizing bacteria, PLoS ONE, 7, e34196, https://doi.org/10.1371/journal.pone.0034196, 2012.

Holmes, R. M., McClelland, J. W., Peterson, B. J., Tank, S. E., Bulygina, E., Eglinton, T. I., Gordeev, V. V., Gurtovaya, T. Y., Raymond, P. A., and Repeta, D. J.: Seasonal and annual fluxes of nutrients and organic matter from large rivers to the Arctic Ocean and surrounding seas, Estuar. Coast., 35, 369-382, 2012.

Holmes, R. M., Coe, M. T., Fiske, G. J., Gurtovaya, T., McClelland, J. W., Shiklomanov, A. I., Spencer, R. G. M., Tank, S. E., and Zhulidov, A. V.: Climate change impacts on the hydrology and biogeochemistry of Arctic Rivers, in: Global Impacts of Climate Change on Inland Waters, edited by: Goldman, C. Kumagai, M., and Robarts, R. D., Wiley, ISBN 9781118470596 , https://doi.org/10.1002/9781118470596, 2013.

Janout, M. A., Hölemann, J., Laukert, G., Smirnov, A., Krumpen, T., Bauch, D., and Timokhov, L.: On the variability of stratification in the freshwater-influenced Laptev Sea Region, Front. Mar. Sci., 7, 543489, https://doi.org/10.3389/fmars.2020.543489, 2020. 
Juhls, B., Stedmon, C. A., Morgenstern, A., Meyer, H., Hölemann, J., Heim, B., Povazhnyi, V., and Overduin, P. P.: Identifying Drivers of Seasonality in Lena River Biogeochemistry and Dissolved Organic Matter Fluxes, Front. Environ. Sci., 8, 53, https://doi.org/10.3389/fenvs.2020.00053, 2020.

Kallistova, A. Y., Savvichev, A. S., Rusanov, I. I., and Pimenov, N. V.: Thermokarst lakes, ecosystems with intense microbial processes of the methane cycle, Microbiology, 88, 649-661, https://doi.org/10.1134/S0026261719060043, 2019.

Kankaala, P., Huotari, J., Peltomaa, E., Saloranta, T., and Ojala, A.: Methanotrophic activity in relation to methane efflux and total heterotrophic bacterial production in a stratified, humic, boreal lake, Limnol. Oceanogr., 51, 1195-1204, 2006.

Kankaala, P., Taipale, S., Nykänen, H., and Jones, R. I.: Oxidation, efflux, and isotopic fractionation of methane during autumnal turnover in a polyhumic, boreal lake, J. Geophys. Res., 112, G02033, https://doi.org/10.1029/2006jg000336, 2007.

Kellogg, C. T. E., McClelland, J. W., Dunton, K. H., and Crump, B. C.: Strong seasonality in arctic estuarine microbial food webs, Front. Microbiol., 10, 2628, doi10.3389/fmicb.2019.02628, 2019.

King, G. M. and Adamsen, A. P.: Effects of temperature on methane consumption in a forest soil and in pure cultures of the methanotroph Methylomonas rubra, Appl. Environ. Microbiol., 58, 2758-2763, 1992.

Kohnert, K., Serafimovich, A., Metzger, S., Hartmann, J., and Sachs, T.: Strong geologic methane emissions from discontinuous terrestrial permafrost in the Mackenzie Delta, Canada, Scient. Rep., 7, 5828, https://doi.org/10.1038/s41598-017-05783-2, 2017.

Kohnert, K., Juhls, B., Muster, S., Antonova, S., Serafimovich, A., Metzger, S., Hartmann, J., and Sachs, T.: Towards understanding the contribution of waterbodies to the methane emissions of a permafrost landscape on a regional scale - a case study from the Mackenzie Delta, Canada, Global Change Biol., 24, 3976-3989, https://doi.org/10.1111/gcb.14289, 2018.

Kruse, S., Bolshiyanov, D., Grigoriev, M. N., Morgenstern, A., Pestryakova, L., Tsibizov, L., and Udke, A.: Russian-German Cooperation: Expeditions to Siberia in 2018, Reports on Polar and Marine Research, Alfred Wegener Institute for Polar and Marine Research, Bremerhaven, p. 257, 2019.

Lantuit, H., Atkinson, D., Overduin, P. P., Grigoriev, M., Rachold, V., Grosse, G., and Hubberten, H.-W.: Coastal erosion dynamics on the permafrost-dominated Bykovsky Peninsula, north Siberia, 1951-2006, Polar Res., 30, 7341, https://doi.org/10.3402/polar.v30i0.7341, 2011.

Leppäranta, M.: Freezing of lakes and the evolution of their ice cover, Springer, Berlin, Heidelberg, 2015.

Liebner, S., Yang, S., Kallmeyer, J., Knoblauch, C., Strauss, J., Jenrich, M., Angelopoulos, M., Overduin, P. P., Damm, E., Bussmann, I., Grigoriev, M. N., Rivkina, E., Biskaborn, B. K., Wagner, D., and Grosse, G.: Microbial controls on the fate of methane along a thermokarst lake to lagoon transition, Internation Online Symposium, Focus Siberian Permafrost - Terrestrial Cryosphere and Climate Change, Institute of Soil Science, University Hamburg, Hamburg, 2021.

Lininger, K. B. and Wohl, E.: Floodplain dynamics in North American permafrost regions under a warming climate and implications for organic carbon stocks:
A review and synthesis, Earth-Sci. Rev., 193, 24-44, https://doi.org/10.1016/j.earscirev.2019.02.024, 2019.

Lofton, D., Whalen, S., and Hershey, A.: Effect of temperature on methane dynamics and evaluation of methane oxidation kinetics in shallow Arctic Alaskan lakes, Hydrobiologia, 721, 209-222, https://doi.org/10.1007/s10750-013-1663-x, 2014.

Magen, C., Lapham, L. L., Pohlman, J. W., Marshall, K., Bosman, S., Casso, M., and Chanton, J. P.: A simple headspace equilibration method for measuring dissolved methane, Limnol. Oceanogr.-Meth., 12, 637-650, https://doi.org/10.4319/lom.2014.12.637, 2014.

Martinez-Cruz, K., Sepulveda-Jauregui, A., Walter Anthony, K., and Thalasso, F.: Geographic and seasonal variation of dissolved methane and aerobic methane oxidation in Alaskan lakes, Biogeosciences, 12, 4595-4606, https://doi.org/10.5194/bg-124595-2015, 2015.

Martinez-Cruz, K., Leewis, M. C., Herriott, I. C., SepulvedaJauregui, A., Anthony, K. W., Thalasso, F., and Leigh, M. B.: Anaerobic oxidation of methane by aerobic methanotrophs in sub-Arctic lake sediments, Sci. Total Environ., 607-608, 23-31, https://doi.org/10.1016/j.scitotenv.2017.06.187, 2017.

Mau, S., Römer, M., Torres, M. E., Bussmann, I., Pape, T., Damm, E., Geprägs, P., Wintersteller, P., Hsu, C. W., Loher, M., and Bohrmann, G.: Widespread methane seepage along the continental margin off Svalbard - from Bjørnøya to Kongsfjorden, Scient Rep., 7, 42997, https://doi.org/10.1038/srep42997, 2017a.

Mau, S., Römer, M., Torres, M. E., Bussmann, I., Pape, T., Damm, E., Geprägs, P., Wintersteller, P., Hsu, C.-W., Loher, M., and Bohrmann, G.: Methane data and stable carbon isotopic composition of methane along the continental margin off Svalbard, PANGAEA, https://doi.org/10.1594/PANGAEA.874412, 2017b.

Morozumi, T., Shingubara, R., Murase, J., Nagai, S., Kobayashi, H., Takano, S., Tei, S., Fan, R., Maximov, T. C., and Sugimoto, A.: Usability of water surface reflectance for the determination of riverine dissolved methane during extreme flooding in northeastern Siberia, Polar Sci., 21, 186-194, https://doi.org/10.1016/j.polar.2019.01.005, 2019.

Newton, A. M. W. and Mullan, D.: Climate change and Northern Hemisphere lake and river ice phenology, The Cryosphere Discuss. [preprint], https://doi.org/10.5194/tc-2020-172, in review, 2020.

Nisbet, E. G., Dlugokencky, E. J., Manning, M. R., Lowry, D., Fisher, R. E., France, J. L., Michel, S. E., Miller, J. B., White, J. W. C., Vaughn, B., Bousquet, P., Pyle, J. A., Warwick, N. J., Cain, M., Brownlow, R., Zazzeri, G., Lanoisellé, M., Manning, A. C., Gloor, E., Worthy, D. E. J., Brunke, E. G., Labuschagne, C., Wolff, E. W., and Ganesan, A. L.: Rising atmospheric methane: 2007-2014 growth and isotopic shift, Global Biogeochem. Cy. 30, 1356-1370, https://doi.org/10.1002/2016GB005406, 2016.

O'Reilly, C. M., Sharma, S., Gray, D. K., Hampton, S. E., and Read, J. S.: Rapid and highly variable warming of lake surface waters around the globe, Geophys. Res. Lett., 42, 1-9, https://doi.org/10.1002/2015GL066235, 2015.

Osudar, R., Liebner, S., Alawi, M., Yang, S., Bussmann, I., and Wagner, D.: Methane turnover and methanotrophic communities in arctic aquatic ecosystems of the Lena Delta, Northeast Siberia, FEMS Microbiol. Ecol., 92, fiw116, https://doi.org/10.1093/femsec/fiw116, 2016. 
Overduin, P. P., Wetterich, S., Günther, F., Grigoriev, M. N., Grosse, G., Schirrmeister, L., Hubberten, H.-W., and Makarov, A.: Coastal dynamics and submarine permafrost in shallow water of the central Laptev Sea, East Siberia, The Cryosphere, 10, 1449-1462, https://doi.org/10.5194/tc-10-1449-2016, 2016.

Overduin, P., Blender, F., Bolshiyanov, D. Y., Grigoriev, M. N., Morgenstern, A., and Meyer, H.: Russian-German Cooperation: Expeditions to Siberia in 2016, Reports on Polar and Marine Research, Alfred Wegener Institute for Polar and Marine Research, Bremerhaven, 295 pp., 2017.

Peterson, B. J., Holmes, R. M., McClelland, J. W., Vörösmarty, C. J., Lammers, R. B., Shiklomanov, A. I., Shiklomanov, I. A., and Rahmstorf, S.: Increasing river discharge to the Arctic Ocean, Science, 298, 2171-2173, https://doi.org/10.1126/science.1077445, 2002.

Platt, S. M., Eckhardt, S., Ferré, B., Fisher, R. E., Hermansen, O., Jansson, P., Lowry, D., Nisbet, E. G., Pisso, I., Schmidbauer, N., Silyakova, A., Stohl, A., Svendby, T. M., Vadakkepuliyambatta, S., Mienert, J., and Lund Myhre, C.: Methane at Svalbard and over the European Arctic Ocean, Atmos. Chem. Phys., 18, 17207-17224, https://doi.org/10.5194/acp-18-17207-2018, 2018.

Prowse, T., Alfredsen, K., Beltaos, S., Bonsal, B., Duguay, C., Korhola, A., McNamara, J., Pienitz, R., Vincent, W. F., Vuglinsky, V., and Weyhenmeyer, G. A.: Past and future changes in Arctic lake and river ice, Ambio, 40, 53-62, https://doi.org/10.1007/s13280-011-0216-7, 2011.

Raven, J. A. and Geider, R. J.: Temperature and algal growth, New Phytol., 110, 441-461, https://doi.org/10.1111/j.14698137.1988.tb00282.x, 1988.

Ricão Canelhas, M., Denfeld, B. A., Weyhenmeyer, G. A., Bastviken, D., and Bertilsson, S.: Methane oxidation at the waterice interface of an ice-covered lake, Limnol. Oceanogr., 61, S78S79, https://doi.org/10.1002/lno.10288, 2016.

Rivera, J., Karabanov, E. B., Williams, D. F., Buchinskyi, V., and Kuzmin, M.: Lena River discharge events in sediments of Laptev Sea, Russian Arctic, Estuar. Coast. Shelf Sci., 66, 185-196, https://doi.org/10.1016/j.ecss.2005.08.009, 2006.

Santibáñez, P. A., Michaud, A. B., Vick-Majors, T. J., D’Andrilli, J., Chiuchiolo, A., Hand, K. P., and Priscu, J. C.: Differential incorporation of bacteria, organic matter, and inorganic ions into lake ice during ice formation, J. Geophys. Res.-Biogeo., 124, 585600, https://doi.org/10.1029/2018JG004825, 2019.

Saunois, M., Bousquet, P., Poulter, B., Peregon, A., Ciais, P., Canadell, J. G., Dlugokencky, E. J., Etiope, G., Bastviken, D., Houweling, S., Janssens-Maenhout, G., Tubiello, F. N., Castaldi, S., Jackson, R. B., Alexe, M., Arora, V. K., Beerling, D. J., Bergamaschi, P., Blake, D. R., Brailsford, G., Brovkin, V., Bruhwiler, L., Crevoisier, C., Crill, P., Covey, K., Curry, C., Frankenberg, C., Gedney, N., Höglund-Isaksson, L., Ishizawa, M., Ito, A., Joos, F., Kim, H. S., Kleinen, T., Krummel, P., Lamarque, J. F., Langenfelds, R., Locatelli, R., Machida, T., Maksyutov, S., McDonald, K. C., Marshall, J., Melton, J. R., Morino, I., Naik, V., O'Doherty, S., Parmentier, F. J. W., Patra, P. K., Peng, C., Peng, S., Peters, G. P., Pison, I., Prigent, C., Prinn, R., Ramonet, M., Riley, W. J., Saito, M., Santini, M., Schroeder, R., Simpson, I. J., Spahni, R., Steele, P., Takizawa, A., Thornton, B. F., Tian, H., Tohjima, Y., Viovy, N., Voulgarakis, A., van Weele, M., van der Werf, G. R., Weiss, R., Wiedinmyer, C., Wilton, D. J., Wiltshire, A., Wor- thy, D., Wunch, D., Xu, X., Yoshida, Y., Zhang, B., Zhang, Z., and Zhu, Q.: The global methane budget 2000-2012, Earth Syst. Sci. Data, 8, 697-751, https://doi.org/10.5194/essd-8-697-2016, 2016.

Saunois, M., Stavert, A. R., Poulter, B., Bousquet, P., Canadell, J. G., Jackson, R. B., Raymond, P. A., Dlugokencky, E. J., Houweling, S., Patra, P. K., Ciais, P., Arora, V. K., Bastviken, D., Bergamaschi, P., Blake, D. R., Brailsford, G., Bruhwiler, L., Carlson, K. M., Carrol, M., Castaldi, S., Chandra, N., Crevoisier, C., Crill, P. M., Covey, K., Curry, C. L., Etiope, G., Frankenberg, C., Gedney, N., Hegglin, M. I., Höglund-Isaksson, L., Hugelius, G., Ishizawa, M., Ito, A., Janssens-Maenhout, G., Jensen, K. M., Joos, F., Kleinen, T., Krummel, P. B., Langenfelds, R. L., Laruelle, G. G., Liu, L., Machida, T., Maksyutov, S., McDonald, K. C., McNorton, J., Miller, P. A., Melton, J. R., Morino, I., Müller, J., Murguia-Flores, F., Naik, V., Niwa, Y., Noce, S., O’Doherty, S., Parker, R. J., Peng, C., Peng, S., Peters, G. P., Prigent, C., Prinn, R., Ramonet, M., Regnier, P., Riley, W. J., Rosentreter, J. A., Segers, A., Simpson, I. J., Shi, H., Smith, S. J., Steele, L. P., Thornton, B. F., Tian, H., Tohjima, Y., Tubiello, F. N., Tsuruta, A., Viovy, N., Voulgarakis, A., Weber, T. S., van Weele, M., van der Werf, G. R., Weiss, R. F., Worthy, D., Wunch, D., Yin, Y., Yoshida, Y., Zhang, W., Zhang, Z., Zhao, Y., Zheng, B., Zhu, Q., Zhu, Q., and Zhuang, Q.: The Global Methane Budget 2000-2017, Earth Syst. Sci. Data, 12, 15611623, https://doi.org/10.5194/essd-12-1561-2020, 2020.

Schleusner, P., Biskaborn, B. K., Kienast, F., Wolter, J., Subetto, D., and Diekmann, B.: Basin evolution and palaeoenvironmental variability of the thermokarst lake E l'gene-K yuele, Arctic Siberia, Boreas, 44, 2016-2229, 2015.

Sepulveda-Jauregui, A., Walter Anthony, K. M., Martinez-Cruz, K., Greene, S., and Thalasso, F.: Methane and carbon dioxide emissions from 40 lakes along a north-south latitudinal transect in Alaska, Biogeosciences, 12, 3197-3223, https://doi.org/10.5194/bg-12-3197-2015, 2015.

Serikova, S., Pokrovsky, O. S., Laudon, H., Krickov, I. V., Lim, A. G., Manasypov, R. M., and Karlsson, J.: High carbon emissions from thermokarst lakes of Western Siberia, Nat. Commun., 10, 1552, https://doi.org/10.1038/s41467-019-09592-1, 2019.

Shiklomanov, A. I. and Lammers, R. B.: River ice responses to a warming Arctic - Recent evidence from Russian rivers, Environ. Res. Lett., 9, 035008, https://doi.org/10.1088/17489326/9/3/035008, 2014.

Shiklomanov, A. I., Holmes, R. M., McClelland, J. W., Tank, S. E., and Spencer, R. G. M.: Arctic Great Rivers Observatory, Discharge Dataset, Version 20191112, available at: https: //arcticgreatrivers.org/discharge/ (last access: December 2019), 2018.

Spangenberg, I.: Methane distribution and hydrochemistry in lake and sea ice from a region of thawing permafrost, Siberia, MS thesis, University of Potsdam, Potsdam, 2018.

Spangenberg, I., Overduin, P. P., Damm, E., Bussmann, I., Meyer, H., Liebner, S., Angelopoulos, M., Biskaborn, B. K., Grigoriev, M. N., and Grosse, G.: Methane Pathways in Winter Ice of Thermokarst Lakes, Lagoons and Coastal Waters in North Siberia, The Cryosphere Discuss. [preprint], https://doi.org/10.5194/tc-2019-304, in review, 2020.

Steinle, L., Maltby, J., Treude, T., Kock, A., Bange, H. W., Engbersen, N., Zopfi, J., Lehmann, M. F., and Niemann, H.: Effects 
of low oxygen concentrations on aerobic methane oxidation in seasonally hypoxic coastal waters, Biogeosciences, 14, 16311645, https://doi.org/10.5194/bg-14-1631-2017, 2017.

Strauss, J., Boike, J., Bolshiyanov, D. Y., Grigoriev, M. N., El-Hajj, H., Morgenstern, A., Overduin, P. P., and Udke, A.: RussianGerman Cooperation: Expeditions to Siberia in 2017, Alfred Wegener Institute for Polar and Marine Research, Bremerhaven, p. 296, 2018.

Tan, Z. and Zhuang, Q.: Arctic lakes are continuous methane sources to the atmosphere under warming conditions, Environ. Res. Lett., 10, 1-9, https://doi.org/10.1088/17489326/10/5/054016, 2015.

Tananaev, N. I., Makarieva, O. M., and Lebedeva, L. S.: Trends in annual and extreme flows in the Lena River basin, Northern Eurasia, Geophys. Res. Lett., 43, 10764-10772, https://doi.org/10.1002/2016GL070796, 2016.

Thibodeau, B., Bauch, D., Kassens, H., and Timokhov, L. A.: Interannual variations in river water content and distribution over the Laptev Sea between 2007 and 2011: The Arctic Dipole connection, Geophys. Res. Lett., 41, 7237-7244, https://doi.org/10.1002/2014GL061814, 2014.

Thottathil, S. D., Reis, P. C. J., and Prairie, Y. T.: Methane oxidation kinetics in northern freshwater lakes, Biogeochemistry, 143, 105-116, https://doi.org/10.1007/s10533-019-00552-x, 2019.

Townsend-Small, A., Åkerström, F., Arp, C. D., and Hinkel, K. M.: Spatial and temporal variation in methane concentrations, fluxes, and sources in lakes in Arctic Alaska, J. Geophys. Res.-Biogeo., 122, 2966-2981, https://doi.org/10.1002/2017JG004002, 2017.

Triputra, P. W.: Greenhouse gases in Siberian ice cores, Master thesis, Faculty of Science, Center of Environmental Sciences, Eötvös Loránd University, Budapest, 2018.

Utsumi, M., Nojiri, Y., Nakamura, T., Nozawa, T., Otsuki, A., Takamura, N., Watanabe, M., and Seki, H.: Dynamic of dissolved methane and methane oxidation in dimictic Lake Nojiri during winter, Limnol. Oceanogr., 43, 10-17, 1998.

Vachon, D., Langenegger, T., Donis, D., and McGinnis, D. F.: Influence of water column stratification and mixing patterns on the fate of methane produced in deep sediments of a small eutrophic lake, Limnol. Oceanogr., 64, 2114-2128, https://doi.org/10.1002/lno.11172, 2019.

Wåhlström, I., Dieterich, C., Pemberton, P., and Meier, H. E. M.: Impact of increasing inflow of warm Atlantic water on the sea-air exchange of carbon dioxide and methane in the Laptev Sea, J. Geophys. Res.-Biogeo., 121, 1867-1883, https://doi.org/10.1002/2015JG003307, 2016.
Walter Anthony, K., Daanen, R., Anthony, P., Schneider von Deimling, T., Ping, C.-L., Chanton, J. P., and Grosse, G.: Methane emissions proportional to permafrost carbon thawed in Arctic lakes since the 1950s, Nat. Geosci., 9, 679-682, https://doi.org/10.1038/ngeo2795, 2016.

Walter, K. M., Smith, L. C., and Stuart Chapin, F.: Methane bubbling from northern lakes: present and future contributions to the global methane budget, Philos. T. Roy. Soc. A, 365, 1657-1676, https://doi.org/10.1098/rsta.2007.2036, 2007.

Wegner, C., Bauch, D., Hölemann, J. A., Janout, M. A., Heim, B., Novikhin, A., Kassens, H., and Timokhov, L.: Interannual variability of surface and bottom sediment transport on the Laptev Sea shelf during summer, Biogeosciences, 10, 11171129, https://doi.org/10.5194/bg-10-1117-2013, 2013.

Wik, M., Johnson, J. E., Crill, P. M., DeStasio, J. P., Erickson, L., Halloran, M. J., Fahnestock, M. F., Crawford, M. K., Phillips, S. C., and Varner, R. K.: Sediment characteristics and methane ebullition in three subarctic lakes, J. Geophys. Res.-Biogeo., 123, 2399-2411, https://doi.org/10.1029/2017JG004298, 2018.

Wild, B., Andersson, A., Bröder, L., Vonk, J., Hugelius, G., McClelland, J. W., Song, W., Raymond, P. A., and Gustafsson, Ö.: Rivers across the Siberian Arctic unearth the patterns of carbon release from thawing permafrost, P. Natl. Acad. Sci. USA, 116, 10280, https://doi.org/10.1073/pnas.1811797116, 2019.

Wilson, S. L., Frazer, C., Cumming, B. F., Nuin, P. A. S., and Walker, V. K.: Cross-tolerance between osmotic and freeze-thaw stress in microbial assemblages from temperate lakes, FEMS Microbiol. Ecol., 82, 405-415, https://doi.org/10.1111/j.15746941.2012.01404.x, 2012.

Winkel, M., Mitzscherling, J., Overduin, P. P., Horn, F., Winterfeld, M., Rijkers, R., Grigoriev, M. N., Knoblauch, C., Mangelsdorf, K., Wagner, D., and Liebner, S.: Anaerobic methanotrophic communities thrive in deep submarine permafrost, Scient. Rep., 8, 1291, https://doi.org/10.1038/s41598-018-19505-9, 2018.

Winterfeld, M., Goñi, M. A., Just, J., Hefter, J., and Mollenhauer, G.: Characterization of particulate organic matter in the Lena River delta and adjacent nearshore zone, NE Siberia - Part 2: Lignin-derived phenol compositions, Biogeosciences, 12, 22612283, https://doi.org/10.5194/bg-12-2261-2015, 2015.

Yang, D., Kane, D. L., Hinzman, L. D., Zhang, X., Zhang, T., and Ye, H.: Siberian Lena River hydrologic regime and recent change, J. Geophys. Res., 107, 4694, https://doi.org/10.1029/2002jd002542, 2002. 